\section{Utfordrende bok om sol og vitamin D}

Bjertness E, red

Solar radiation and human health

265 s, ill. Oslo: Novus, 2008.

Pris NOK 285

ISBN 978-82-7099-485-4

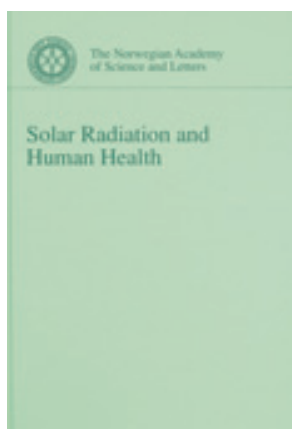

Her er alle foredragene som ble presentert på symposiet Solar Radiation and Human Health i Vitenskapsakademiet i mai 2007. Av 19 kapitler er 14 forfattet av nordmenn, resten av forfatterne er fra USA og Tyskland. Det er ranser etter hvert kapittel. rikelig med refe-

Det er stor bredde i temaene som omhandles. I flere kapitler omtales fysiske forhold, hvordan de ultrafiolette (UV) strålene passerer atmosfæren og hvordan de fordeles og absorberes i huden. Evolusjonsmessige forhold ved livet på jorden, tilpasningen til UV-stråling og utvikling av de ulike hudfargene er egne temaer. I to av kapitlene forklares lysets betydning for den biologiske klokken, det gjelder både døgnvariasjon og svingninger gjennom året.

UV-stråler, vitamin D og helseeffekter er de viktigste temaene. Det dreier seg om DNA-skader, mutasjoner og hudkreft, men først og fremst om vitamin D som nødvendig faktor for å hindre utvikling av ulike krefttyper og autoimmune sykdommer. Flere forfattere viser til epidemiologiske studier som konkluderer med at høy soleksposisjon og dermed høy vitamin D-produksjon gir lavere insidens av en rekke sykdommer og bedre prognose ved oppstått sykdom. Det gis også en oversikt over vitamin D-status i den norske befolkningen og anbefalinger om vitamin D i kosten. Bruk av solarium anbefales, da den økte vitamin D-produksjonen gir en «netto helseeffekt» selv om hyppigheten av hudkreft øker.

Solar radiation and human health gir mye kunnskap om lysets egenskaper. Man får god innsikt i produksjon og funksjon av vitamin D. Dette er et godt grunnlag for debatt om hvilke nivåer av vitamin $\mathrm{D}$ som bør anbefales i kosten. Økt soleksposisjon som helsefremmende tiltak er et interessant og kontroversielt spørsmål. Denne boken kan oppfattes som et partsinnlegg i diskusjonen om hva som bør være vår viktigste kilde til vitamin $\mathrm{D}$.

Rikshospitalet

\section{Kunsten å få det til}

Clavien P-A, Sarr MG, Fong Y, red

Atlas of upper gastrointestinal and hepatopancreato-biliary surgery

990 s, tab, ill. Berlin: Springer, 2007.

Pris EUR 299

ISBN 978-3-540-20004-8

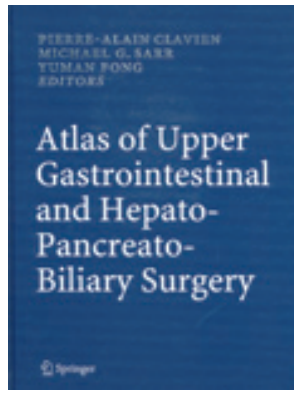

Vellykket kirurgi forutsetter blant annet kunnskap om anatomi, operasjonsmetoder og god kirurgisk teknikk. Utvalget av prosedyrer utvides stadig, særlig gjelder det laparoskopiske teknikker. Utdanningsmessig er det ingenting som slår det å operere sammen med erfarne og dyktige kirurger. Et godt operasjonsatlas kan være et nyttig hjelpemiddel for å forberede seg før man entrer operasjonsstuen.

Dette ble utgitt i fjor og er laget for leger under utdanning og for spesialister i generell og gastrointestinal kirurgi. Forfatterne legger vekt på tekniske aspekter ved gastrokirurgiske prosedyrer og henviser til kirurgiske lærebøker for utfyllende informasjon.

Redaktørene ønsker å formidle en oppdatert oversikt over de fleste operative prosedyrer på området, åpne og laparoskopiske fra de enkleste, som laparoskopisk kolecystektomi, til de mest avanserte, som levereller pancreastransplantasjon. Det skulle de ha gode forutsetninger for, alle tre er meget erfarne og ledende akademiske kirurger innen de aktuelle disipliner. De har med seg 159 bidragsytere, de fleste profilerte kirurger - mange av dem har vært med på å utvikle prosedyrene de beskriver. Det er sju deler, som dekker hele fagfeltet. Den første omhandler generelle kirurgiske prinsipper, som leiring av pasient, kirurgiske tilganger, bruk av forskjellige selvholdende haker, suturmaskiner og dren. De øvrige tar for seg inngrep knyttet til oesophagus, ventrikkel og duodenum, lever, galleveier, portal hypertensjon, pancreas og milt.

Prosedyrebeskrivelsene innledes med en kortfattet tekst om indikasjoner og kontraindikasjoner, preoperative undersøkelser og forberedelser, så er det en stegvis gjennomgang av dem. Stort sett gir tekst og bilder en passe detaljert fremstilling. Postoperativ oppfølging og vanlige komplikasjoner er listet opp. Avslutningsvis avslører forfatterne et triks eller to, ofte nyttige erfaringsbaserte tekniske og taktiske råd.

Utvalget av prosedyrer er meget stort. Et kapittel på 75 sider er viet kirurgisk behandling av portal hypertensjon. Det er en prioritering som redaktørene argumenterer for, men som kanskje kan diskuteres. Samtidig savnes enkelte prosedyrer, for eksempel biliopankreatisk avledning med duodenal omkobling ved sykelig overvekt. Generelt er de åpne prosedyrene mer vektlagt enn de laparoskopiske.

Mange norske kirurger vil nok ha sine små variasjoner av det som beskrives i atlaset. For eksempel er det vanlig å dekke perforerte magesår med en omentflik i tillegg til sutur, og de fleste velger sikkert maskinsydd øsofagojejunal anastomose etter total gastrektomi. Postoperativ drenasje anbefales mer utstrakt enn det er dekning for $i$ litteraturen og redegjort for i innledningskapitlet.

De 950 illustrasjonene - mange i farger av kunstneren Jörg Kühn holder meget høy kvalitet og balanserer didaktisk klarhet mot anatomisk gjengivelse og fokuserer på teknisk viktige detaljer.

Atlas of upper gastrointestinal and hepato-pancreato-biliary surgery er et glimrende operasjonsatlas, vel verdt de mange pengene det koster. Anbefales!

Oddvar Sandvik

Kirurgisk avdeling

Stavanger universitetssjukehus

\section{Godt om genetisk screening og etiske problemer}

Cowan RS.

\section{Heredity and hope}

The case for genetic screening. 292 s, ill. London: Harvard University Press, 2008.

Pris GBP 19

ISBN 978-0-674-02424-3

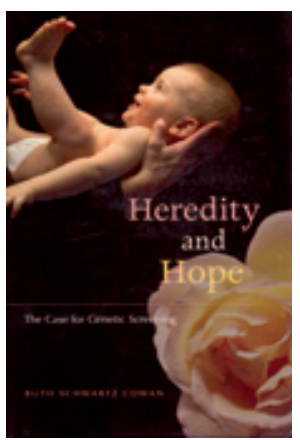

Etter hvert som tilbudet om genetiske undersøkelser utvides, blir både fagpersonell og pasienter konfrontert med viktige spørsmål som informert samtykke, etiske vurderinger og konsekvenser for nær familie ved ulike genetiske tester. Det er ventet at allmennleger i økende grad må overta mer av informasjonen til pasienten om genetiske undersøkelser, både fosterdiagnostikk og andre genetiske tester, som til nå har vært gitt av andre spesialister. Heredity and hope er aktuell både for medisinere, andre yrkesgrupper og det generelle publikum.

Masseundersøkelser av nyfødte for fenylketonuri (PKU; Føllings sykdom) startet omkring 1960 og ble i vårt land raskt en selvfølgelig del av de offentlige helseundersøkelser. Da bioteknologiloven ble etablert i 1994, hadde man faktisk oversett at PKUscreening etter denne loven krevde informert 